Al IBTIDA 3 (2): 253-268

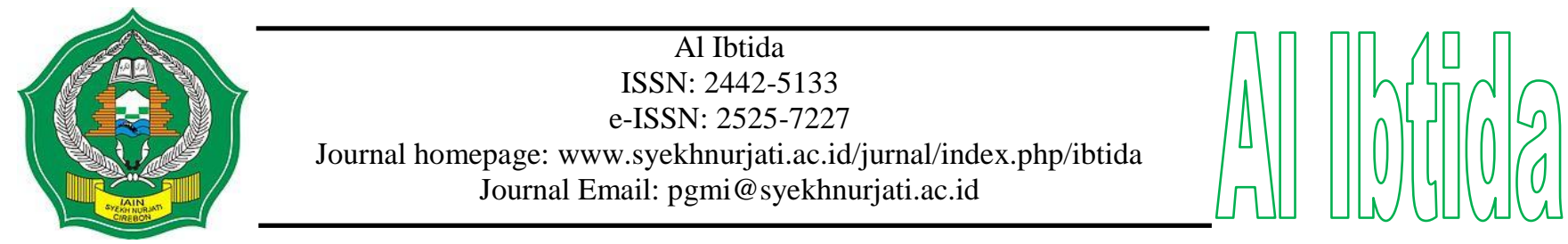

\title{
PENGARUH KUALITAS INTERAKSI SOSIAL DI LINGKUNGAN KELUARGA TERHADAP PRESTASI BELAJAR SISWA (Studi Kasus di SMA Negeri 5 Samarinda)
}

\author{
Siti Murti* \\ *Sekolah Menengah Atas Negeri 5 Samarinda \\ Email: sitimurti88@yahoo.co.id \\ Heryanto* \\ *Fakultas Ekonomi dan Bisnis Universitas Mulawarman \\ Email: heryfe@yahoo.cp.id
}

\begin{abstract}
Abstrak
Penelitian ini bertujuan untuk mengungkap dan mengevaluasi kualitas interaksi sosial di lingkungan keluarga terhadap prestasi belajar siswa. Pendekatan penelitian yang digunakan ialah metoda deskriptif atau sering disebut juga taxonomic research yaitu untuk mengeksplorasi dan mengklarifikasi suatu fenomena sosial dengan mendeskripsikan sejumlah variabel yang berkenaan dengan masalah unit yang diteliti. Metode penentuan sampel sebagai unit analisis menggunakan teknik simple random sampling secara proporsional. Hasil penelitian memperlihatkan bahwa kualitas interaksi sosial di lingkungan keluarga berpengaruh signifikan terhadap prestasi belajar siswa. Semakin baik kualitas interaksi sosial orang tua dengan anak maka semakin baik prestasi belajar siswa.
\end{abstract}

Kata kunci: interaksi, keluarga, prestasi, siswa

\begin{abstract}
The purpose of this study was to uncover and evaluate the quality of social interaction in the family environment on student achievement. The approach used in this study is descriptive method or often called the taxonomic research is to explore and clarify a social phenomenon by describing a number of variables relating to issues under investigation unit. Determination of the sample as a unit of analysis used simple random sampling technique proportionally. The results showed that the quality of social interaction in the family environment have a significant effect on student achievement. The better quality of a social interaction between parent and child, then led to a better performance.
\end{abstract}

Keywords: interaction, family, achievement, students 


\section{PENDAHULUAN}

Saat ini beban sekolah dalam membina dan mendidik siswanya semakin berat dan meluas, bahkan kondisi ini diperparah oleh pandangan orang tua yang tidak memiliki beban mendidik setelah anaknya disekolahkan. Tugas orang tua hanya menyelesaikan administrasi yang diperlukan oleh sekolah, selebihnya menjadi tanggung jawab sekolah. Konflik orang tua dan sekolah sering muncul manakala terjadi penyimpangan pada perilaku siswa. Orang tua akan menyalahkan sekolah yang tidak mampu memberikan pendidikan terhadap anaknya, di lain pihak sekolah memiliki keterbatasan dalam mendidik siswanya. Padahal Plato memberikan penegasan bahwa keluarga merupakan tempat di mana si bayi mendapat didikan pertama dari orang tuanya. Menurut Widana (2016) lingkungan keluarga memberikan pengaruh pertama terhadap pembentukan kepribadian seseorang.

Berkenaan dengan pendapat tersebut, pendidikan di lingkungan keluarga memiliki kontribusi yang positif terhadap perkembangan jiwa dan intelektual anak. Peran keluarga saat ini kurang disadari oleh para orang tua siswa. Penyelenggaraan pendidikan harus menjadi tanggung jawab bersama yaitu orang tua, sekolah, masyarakat dan pemerintah sesuai dengan tugas dan fungsinya masing. Orang tua, sekolah, masyarakat, dan pemerintah hendaknya bersinergi membangun penyelenggaraan pendidikan yang kondusif. Penyelenggaraan pendidikan tidak hanya pelaksaan perintah atau amanat undang-undang tetapi juga merupakan pelaksanaan perintah Allah, Tuhan Yang Maha Esa. Dalam Surat Al-Alaq: 1-5 dijelaskan perintah itu sebagai berikut: "Bacalah dengan meyebut nama Tuhanmu yang menciptakan. Dia telah menciptakan manusia dari segumpal darah. Bacalah, dan Tuhanmulah yang Maha Mulia. Yang mengajar manusia dengan pena. Dia mengajarkan manusia apa yang tidak diketahuinya".

Pendidikan pada hakekatnya bertujuan untuk meningkatkan harkat dan martabat manusia yang berbudi luhur dan menjalankan pengembangan warga negara yang bebas, rasional dan penuh tanggung jawab. Penyelenggaraan pendidikan harus ditujukan pada kepentingan pembangunan masa sekarang dan masa yang akan datang. Oleh karena itu penyelenggaraan pendidikan memiliki dimensi waktu yang ditujukan untuk masa kini (sekarang) dan masa yang akan datang. Tujuan dan fungsi pendidikan nasional yang tercantum dalam Undang-undang Nomor 20 tahun 2003 pasal 3 menyatakan bahwa Pendidikan Nasional berfungsi mengembangkan kemampuan dan membentuk watak serta 
peradaban bangsa yang bermartabat dalam rangka mencerdaskan kehidupan bangsa bertujuan untuk mengembangkan potensi peserta didik agar menjadi manusia yang beriman dan bertakwa kepada Tuhan Yang Maha Esa, berakhlak mulia, sehat, berilmu, cakap, kreatif, mandiri dan menjadi warga Negara yang demokratis serta bertanggung jawab.

Pada hakekatnya penyelengaraan pendidikan adalah untuk membentuk manusia yang beriman dan bertaqwa kepada Tuhan Yang Maha Esa serta berakhlak mulia. Selain memiliki keimanan dan ketaqwaan yang berakhlak mulia juga perlu memiliki ilmu, kecakapan, kreativitas, mampu mandiri dan berjiwa demokratis. Kondisi pendidikan di Kalimantan Timur memperlihatkan perkembangan yang menggembirakan. Data human development index (HDI) Kalimantan Timur mengalami peningkatan setiap tahunnya. Pada tahun 2012, 2013, dan 2014 besaran HDI adalah 72,62 73,21 dan 73,82. Ini menunjukkan bahwa pembangunan sumber daya manusia di Kalimantan Timur menunjukkan kemajuan yang berarti.

Tujuan penelitian ini ialah mengungkap dan mengevaluasi pengaruh interaksi sosial di lingkungan keluarga terhadap prestasi belajar siswa. Harapan yang ingin diperoleh ialah mewujudkan model pendidikan, baik di lingkungan keluarga maupun lembaga pendidikan (sekolah). Melalui model ini akan nampak secara jelas benang merah penyelenggaraan pendidikan anak di sekolah sebagai kelanjutan dari pendidikan keluarga. Dengan demikian kesalahpahaman atau mis-komunikasi antara orang tua siswa dengan lembaga pendidikan dapat dihindari, sebaliknya dapat membangun sinergi kedua belah pihak yang memungkinkan anak dapat berkembang secara optimal dalam mencapai kedewasaannya.

Keluarga merupakan kelompok kecil yang memiliki pemimpin dan anggota, mempunyai tugas dan kerja serta hal dan kewajiban bagi masing-masing anggotanya (Helmawati, 2014). Orang tua harus memberikan perhatian terhadap anak-anaknya karena perhatian orang tua menjadi bagian integral dari perkembangan anak sebagai anggota keluarga. Wahyudin (2009) dalam penelitiannya menyimpulkan bahwa perhatian keluarga berpengaruh yang signifikan terhadap prestasi belajar. Oleh karena itu kondisi lingkungan keluarga harus harmonis sehingga memungkinkan terjadinya perkembangan fisik dan psikis anak secara sehat. Mengadopsi teori lingkungan keluarga sebagai tempat hidup dan belajar anak dari Dorothy Law Nolte, maka: (1) jika anak hidup dengan kecaman ia akan belajar mencaci atau mengutuk; (2) jika anak hidup dengan penuh permusuhan, ia akan belajar berkelahi; (3) jika anak hidup dengan penuh perasaan malu, ia akan belajar merasa bersalah; 
(4) jika anak hidup penuh dengan toleran, ia akan belajar bersabar; (5) jika anak hidup penuh dengan dorongan semangat, ia akan belajar percaya diri; (6) jika anak hidup dengan penuh pujian, ia akan belajar menghargai; (7) jika anak hidup dengan penuh kejujuran, ia akan belajar keadilan; (8) jika anak hidup dengan penuh rasa aman, ia akan belajar beriman; (9) jika anak hidup penuh dengan restu (pembenaran), ia akan belajar menyukai dirinya; dan (10) jika anak hidup penuh dukungan/rasa diterima dan persahabatan, ia akan belajar menemukan cinta-kasih di masyarakat.

Upaya untuk mencapai perkembangan pribadi anak, Heryanto (1996) menyarankan kondisi lingkungan keluarga perlu diarahkan agar anak hidup dalam suasana sebagai berikut: terhindar dari kehidupan keluarga yang penuh cacian, permusuhan, dan perasaan malu yang tidak pada tempatnya, tetapi perlu dibina kehidupan keluarga penuh toleran, dorongan semangat, pujian, kejujuran, restu, aman, dan persahatan, sehingga jiwa dan kepribadian anak akan tumbuh sesuai harapan. Violita (2013) dalam risetnya menyimpulkan bahwa lingkungan keluarga berupa perhatian dan pengawasan dalam belajar mempunyai pengaruh terhadap peningkatan prestasi siswa. Implementasi temuan ini pada keluarga bisa dalam bentuk partisipasi orang tua dalam membantu proses belajar siswa, seperti memberikan semangat atau membantu menyelesaikan tugas-tugas belajar anaknya.

Selanjutnya Aditya dkk. (2013) menyimpulkan bahwa partisipasi orang tua dalam mendidik di lingkungan keluarga berpengaruh terhadap prestasi belajar siswa, dan besarnya pengaruh partisipasi orang tua dalam mendidik di lingkungan keluarga terhadap prestasi belajar siswa adalah sebesar 55,9\%. Selain bentuk partisipasi, juga cara orang tua mendidik anak, relasi antara anggota keluarga, suasana rumah tangga, dan keadaan ekonomi keluarga (Slameto, 2010). Gonzalez dan Wolters (2006) yang dikutif Aditya dkk (2013) menyatakan bahwa partisipasi orang tua mencerminkan sejauh mana orang tua hadir dan menyisipkan diri mereka ke dalam kehidupan anak-anaknya. Menurut Wirdhana dkk (2012) terdapat delapan fungsi keluarga dalam kehidupan, yaitu fungsi agama, sosial budaya, cinta kasih sayang, perlindungan, reproduksi, sosialisasi dan pendidikan, ekonomi dan lingkungan.

Berdasarkan hasil temuan tersebut maka kedudukan keluarga dalam mendidik kepribadian anak memegang peran yang sangat penting. Kesalahan dalam mendidik anak akan menyebabkan hambatan atau kendala bagi perkembangan jiwa selanjutnya. Suasana yang harmonis, hangat, akrab dan penuh persabahatan mendorong pertumbuhan jiwa yang 
baik. Anak yang kurang mendapat kasih sayang dari orang tuanya akan menimbulkan berbagai kesukaran pada diri anak, baik kesukaran dari segi emosional maupun dari segi perkembangan intelektual anak (Nasruddin, 2009). Oleh karena itu kasih sayang orang tua perlu diwujudkan dalam kehidupan anak.

Riset lain yang terkait dengan prestasi belajar adalah temuan bahwa tingkat pendidikan orang tua berpengaruh signifikan terhadap prestasi belajar siswa (Dasmo, dkk, 2015). Hal ini mudah dipahami karena orang tua yang memiliki tingkat pendidikan yang tinggi tentu memiliki wawasan yang luas sehingga mampu memberikan pandangan alternatif atau opsi yang banyak terhadap anaknya. Berbeda dengan orang tua yang memiliki pengetahuan terbatas, tentu menganggap bahwa pendidikan merupakan tugas lembaga sekolah secara penuh, sehingga keberhasilan belajar siswa bukan tanggung jawab keluarga.

Keberhasilan belajar siswa atau prestasi belajar merupakan hasil dari suatu interaksi tindak belajar dan tindak mengajar (Dimyati dan Mudjiono, 1999). Hal ini berarti prestasi belajar merupakan kegiatan yang aktif bukan pasif, siswa harus melakukan suatu tindakan, yaitu belajar. Pada sisi lain, guru harus secara aktif melakukan tindakan mengajar. Tindakan mengajar mungkin terbatas hanya dapat dilakukan di sekolah tetapi tindakan belajar yang dilakukan siswa bisa dilaksanakan di sekolah maupun di rumah (keluarga). Riset Widhirahmadi (2015) menyimpulkan bahwa secara parsial kondisi lingkungan keluarga berpengaruh terhadap prestasi belajar anak. Maka dari itu kondisi lingkungan keluarga perlu dibangun kondusif terutama interaksi sosial antara anggota keluarga. Fitriastuti (2013) menyatakan terdapat pengaruh yang positif dan signifikan antara interaksi sosial dalam keluarga terhadap prestasi belajar siswa, sumbangan efektifnya sebesar 70,73\%.

Naiknya Human Development Index di Kalimantan Timur tidak terlepas dari peran pendidikan yang dilakukan di lingkungan persekolahan maupun keluarga. Menurut Astuti (2015) lingkungan keluarga berpengaruh positif terhadap prestasi belajar. Penyataan ini memberi gambaran bahwa lingkungan keluarga yang baik memberikan pengaruh yang baik pula terhadap pendidikan anak di lembaga persekolahan. Sebaliknya lingkungan keluarga yang buruk memberi dampak yang buruk pula terhadap hasil pendidikan di sekolah. Hal ini sesuai dengan pernyataan bahwa lingkungan merupakan laboratorium kehidupan yang dapat berdampak positif sehingga memperlancar proses belajar mengajar, namun disisi lain juga berdampak negatif yang menimbulkan kesulitan belajar bagi anak (Widana, 2016). Atas dasar 
ini, kajian terhadap pengaruh interaksi sosial keluarga dengan prestasi belajar siswa di Kota Samarinda sangat menarik untuk dikaji. Kota Samarinda sebagai pusat pemerintahan, perdagangan, dan industri tentu memberi karakteristik terhadap orang tua dalam mendidik dan merawat anak-anaknya.

\section{METODE PENELITIAN}

Pendekatan penelitian yang digunakan dalam penelitian ini ialah metode deskriptif atau sering disebut juga taxonomic research yaitu untuk mengeksplorasi dan mengklarifikasi suatu fenomena sosial dengan mendeskripsikan sejumlah variabel yang berkenaan dengan masalah unit yang diteliti. Pendekatan yang digunakan ini cukup relevan, karena tujuan dari penelitian ini ialah untuk memberikan suatu gambaran yang realistis tentang pengaruh kualitas interaksi sosial di lingkungan keluarga terhadap prestasi belajar siswa di Sekolah Menengah Atas Negeri 5 Samarinda.

Sementara itu, populasi dalam penelitian ini ialah siswa Sekolah Menengah Atas Negeri 5 Kota Samarinda. Sampel penelitian diambil secara probabilistik dengan simple random sampling secara proporsional, yaitu suatu teknik pengambilan sampel dilakukan secara acak sederhana. Ukuran sampel menggunakan rumus $\mathrm{n} \geq\left\{\left(\mathrm{z}_{0.5 \gamma} \times \theta\right)^{2} / \mathrm{k}\right\}$ (Sudjana, 1996), dengan simpang baku terdahulu 0,279 (Heryanto) maka sampel seluruhnya 129 siswa. Distribusi masing-masing kelas disajikan dalam Tabel 1 berikut.

Tabel 1. Distribusi Ukuran Sampel Penelitian

\begin{tabular}{|c|c|c|c|c|c|c|c|c|c|}
\hline & Kelas & L & P & Total & & Kelas & L & P & Total \\
\hline IPSX & 1 & 1 & 3 & 4 & IPAX & 1 & 1 & 3 & 4 \\
\hline & 2 & 2 & 4 & 6 & & 2 & 1 & 2 & 3 \\
\hline & 3 & 2 & 2 & 4 & & 3 & 2 & 2 & 4 \\
\hline & 4 & 2 & 2 & 4 & & 4 & 2 & 2 & 4 \\
\hline & 5 & 1 & 2 & 3 & & 5 & 2 & 2 & 4 \\
\hline IPSXI & 1 & 2 & 3 & 5 & IPAXI & 1 & 1 & 4 & 5 \\
\hline & 2 & 1 & 3 & 4 & & 2 & 1 & 3 & 4 \\
\hline & 3 & 1 & 3 & 4 & & 3 & 3 & 2 & 5 \\
\hline & 4 & 3 & 2 & 5 & & 4 & 3 & 1 & 4 \\
\hline & 5 & 2 & 2 & 4 & & 5 & 3 & 2 & 5 \\
\hline IPSXII & 1 & 1 & 3 & 4 & IPAXII & 1 & 1 & 3 & 4 \\
\hline & 2 & 1 & 3 & 4 & & 2 & 2 & 2 & 4 \\
\hline & 3 & 2 & 3 & 5 & & 3 & 2 & 2 & 4 \\
\hline \multicolumn{6}{r}{} \\
\hline
\end{tabular}

Sumber: Diolah dari Dari Siswa SMAN 5 Samarinda, 2016. 
Data yang diperlukan untuk mendeskripsikan tentang pengaruh dan kontribusi kualitas interaksi sosial di lingkungan keluarga terhadap prestasi belajar yang diperoleh siswa Sekolah Menengah Atas Negeri 5 Samarinda, antara lain data tentang siswa, interaksi sosial di lingkungan keluarga siswa, dan prestasi belajar yang diperoleh siswa. Data kualitas interaksi sosial di lingkungan keluarga diperoleh dari sumber primer, sedangkan data prestasi siswa sebagai data sekunder melalui dokumen yang tersedia.

Data penunjang untuk melengkapi data pokok penelitian diperoleh melalui pengamatan, dan wawancara. Pengamatan merupakan kegiatan peneliti untuk menangkap halhal yang dilihat, didengar, dirasakan tanpa mengubah konteksnya. Wawancara merupakan kegiatan tanya-jawab dalam upaya mendapatkan data yang diperlukan. Dua variabel yang menjadi perhatian penelitian adalah variabel kualitas interaksi sosial di lingkungan keluarga yang disebut variabel $\mathrm{X}$ dan prestasi belajar siswa yang disebut varibel Y. Variabel $\mathrm{X}$ merupakan variabel independent (bebas), dan varial $\mathrm{Y}$ merupakan variabel dependent (tergantung).

Secara umum ada beberapa tahapan yang dilakukan dalam penelitian di lapangan, yaitu pra-survey, orientasi pendahuluan, mengumpulkan data, analisis data, pengujian hipotesis dan penulisan laporan.

1. Melaksanakan orientasi pendahuluan, yaitu kegiatan mengenal medan penelitian dan mendekatkan hubungan antar pribadi dengan kepala sekolah, wakil kepala sekolah, guruguru, dan staf administrasi Sekolah Menengah Atas Negeri 5 Samarinda, agar mereka dapat menerima kehadiran peneliti dalam suasana yang akrab penuh kekeluargaan.

2. Mengumpulkan data, yaitu kegiatan memperoleh informasi melalui observasi, wawancara, dan dokumentasi. Pada tahap mengumpulkan data ini, peneliti mencatat hal-hal yang didengar, dilihat, dan dirasakan tanpa mengubah konteks aslinya. Observasi yaitu kegiatan meninjau secara langsung obyek penelitian di Sekolah Menengah Atas Negeri 5 Samarinda. Wawancara yaitu melakukan tanya-jawab dengan kepala sekolah, wakil kepala sekolah, guru-guru, dan staf administasi.

3. Dokumentasi yaitu kegiatan mempelajari masalah penelitian melalui dokumen yang tersedia di SMA Negeri 5 Samarinda. 
4. Analisis data dan pengujian hipotesis, yaitu menganalisis terhadap data hasil penelitian melalui interpretasi data untuk diperoleh maknanya. Ada dua analisis yang digunakan, yaitu: (a) analisis korelasi dan (b) regresi.

5. Pengujian hipotesis terdiri atas uji koefisien regresi dan korelasi. Koefisien regresi diuji dengan Anava (Analisis Varian) atau dikenal dengan istilah uji-F, sedangkan koefisien korelasi diuji dengan uji-t. Keseluruan uji-F dan uji-t dengan cara membandingkan $\alpha$ hitung (sig. $\alpha$ ) dengan 0,05 , jika nilai $\alpha$ hitung (sig. $\alpha$ ) lebih kecil dari 0,05 maka hipotesis penelitian alternatif diterima dan menolak hipotesis nul.

\section{HASIL DAN PEMBAHASAN}

\section{A. Hasil Penelitian}

1. Deskripsi data hasil angket kualitas interaksi sosial di lingkungan keluarga

Berdasarkan hasil observasi dan pengumpulan data melalui angket yang terkait dengan kualitas interkasi sosial di lingkungan keluarga diketahui bahwa skor rata-rata (mean) interaksi sosial di lingkunan keluarga adalah 33,7674. Skor minimum 13, sedangkan maksimum 49 dengan simpang baku 8,37268 serta median 34,0000. Hasil ini menunjukkan bahwa 51,2\% siswa memperoleh skor di atas 34,0000 dan sebagian lagi $(48,8 \%)$ di bawah 34,0000. Ini berarti kualitas interaksi sosial siswa di lingkungan keluarga ada pada kategori cukup. Untuk melihat gambaran kualitas interaksi sosial orang tua siswa dengan anaknya disajikan dalam Tabel 2 berikut ini.

Tabel 2. Gambaran Kualitas Interaksi Sosial Orang Tua dengan Anak

\begin{tabular}{|c|c|c|c|}
\hline Uraian & Skor & F & $\%$ \\
\hline Baik & Di atas 42.80 & 23 & 17.83 \\
& $35.61-42.80$ & 31 & 24.03 \\
& $28.41-35.60$ & 42 & 32.56 \\
& $21.21-28.40$ & 20 & 15.50 \\
Buruk & Kurang dari 21.21 & 13 & 10.08 \\
\hline \multicolumn{2}{|r|}{ JUMLAH } & 129 & 100,00 \\
\hline
\end{tabular}

Sumber: Diolah dari angket, 2016.

Berdasarkan data Tabel 2 di atas, sebanyak 17,83\% memperoleh skor kondisi kualitas interaksi sosial di lingkungan keluarga di atas 42,80, dan sebanyak 10,08\% berskor di bawah 21.21. Hasil wawancara yang dilakukan dengan beberapa orang-tua siswa, pada umumnya mereka memberikan perlakukan yang terbaik untuk keberhasilan belajar anaknya, namun ada beberapa responden yang didesak oleh 
himpitan ekonomi dan kepentingan lain, terkadang kepentingan sekolah anak dikesampingan. Berangkali atas hal inilah sering memicu konflik antara kepentingan anak dan kepentingan keluarga, yang sering mengundang anak menjadi bersikap berontak, melawan/protes atas ketidakmampuan orang-tuanya. Anak memandang atau menilai yang sebaliknya dengan tujuan orang tua.

2. Deskripsi prestasi belajar siswa

Pendekatan yang digunakan untuk mengetahui prestasi belajar siswa ialah studi dokumenrasi. Raport siswa dipakai sebagai gambaran prestasi belajar siswa di Sekolah Menengah Atas Negeri 5 Samarinda. Hasil studi dokumentasi diperoleh gambaran bahwa skor total seluruh mata pelajaran tertinggi 49,65 sebanyak 13,18\%, sedangkan terrendah 42,25 sebanyak 0,78\%. Skor rata-rata adalah 45,88 dengan median 46,22. Hal ini menunjukkan bahwa sebagian siswa SMA Negeri 5 Samarinda memperoleh skor di atas 46,22 dan sebagian di bawah 46,22. Dengan demikian prestasi belajar siswa pada umumnya lebih dari cukup. Gambaran yang jelas tentang prestasi yang diperoleh siswa disajikan pada Tabel 3 berikut ini.

Tabel 3. Prestasi Belajar Siswa Semester Gasal 2015/2016

\begin{tabular}{|c|c|c|c|}
\hline No & Prestasi Belajar & $\mathrm{f}$ & $\%$ \\
\hline 1 & Di atas 49.65 & 17 & 13.18 \\
2 & $47.80-49.64$ & 49 & 37.98 \\
3 & $45.95-47.79$ & 50 & 38.76 \\
4 & $44.10-45.95$ & 12 & 9.30 \\
5 & $42.25-44.09$ & 1 & 0.78 \\
\hline & Jumlah & 129 & 100.00 \\
\hline
\end{tabular}

Sumber: Diolah dari Nilai Raport, 2016.

3. Uji asumsi statistik

Sebagaimana dijelaskan di muka bahwa analisis data yang digunakan adalah korelasi dan regresi linier maka ada beberapa persyaratan yang harus dipenuhi seperti normalitas, homogenitas dan linieritas.

Uji normalitas

Hasil uji asumsi statistik normalitas menunjukkan data kualitas interaksi sosial di lingkungan keluarga dan prestasi belajar siswa memperlihatkan data yang berdistribusi normal sebagaimana diperlihatkan oleh Tabel 4 berikut: 
Tabel 4. Tests of Normality

\begin{tabular}{|c|r|r|r|r|r|r|}
\hline & \multicolumn{3}{|c|}{ Kolmogorov-Smirnov $^{\text {a }}$} & \multicolumn{3}{|c|}{ Shapiro-Wilk } \\
\cline { 2 - 7 } & Statistic & \multicolumn{1}{c|}{ Df } & \multicolumn{1}{c|}{ Sig. } & Statistic & \multicolumn{1}{c|}{ Df } & \multicolumn{1}{c|}{ Sig. } \\
\hline Insoskel (X) & .060 & 129 & $.200^{*}$ & .979 & 129 & .057 \\
Prestasi (Y) & .084 & 129 & .077 & .979 & 129 & .063 \\
\hline
\end{tabular}

*. This is a lower bound of the true significance.

a. Lilliefors Significance Correction

Berdasarkan data pada Tabel 4 di atas dapat disimpulkan bahwa data variabel kualitas interaksi sosial (insoskel, X) berdistribusi normal karena $\alpha$ hitung (sig. $\alpha$ ) sebesar 0,200 lebih besar dari 0,05. Begitu juga dengan variabel $\mathrm{Y}$, data prestasi belajar siswa berdistribusi normal yang ditunjukkan $\alpha$ hitung (sig. $\alpha$ ) sebesar 0,77 lebih besar dari 0,05. Dengan demikian kedua data telah memenuhi syarat uji asumsi statistik normalitas.

Uji homogenitas

Uji homogenitas diperlukan untuk melihat homogen tidaknya data yang akan dianalisis. Data yang tidak homogen tidak dapat diuji secara statistik melalui analisis regresi linier. Berdasarkan uji homogenitas ternyata data hasil penelitian bersifat homogen karena nilai $\alpha$ yang dihasilkan (sig. $\alpha$ ) lebih besar dari 0,05. Gambaran yang jelas disajikan dalam Tabel 5 berikut.

Tabel 5. Test of Homogeneity of Variance

\begin{tabular}{|c|c|c|c|c|c|}
\hline & & $\begin{array}{c}\text { Levene } \\
\text { Statistic }\end{array}$ & df1 & df 2 & Sig. \\
\hline \multirow[t]{4}{*}{ Prestasi } & Based on Mean & 1.527 & 4 & 124 & .198 \\
\hline & Based on Median & 1.580 & 4 & 124 & .184 \\
\hline & Based on Median and with adjusted df & 1.580 & 4 & 115.971 & .184 \\
\hline & Based on trimmed mean & 1.598 & 4 & 124 & .179 \\
\hline
\end{tabular}

Sumber: Print-out SPSS versi 22, 2016.

Uji-linieritas

Analisis korelasi dan regresi linier mempersyaratkan asumsi statistik linieritas, maka data hasil penelitian diuji linieritasnya menggunakan perangkat SPSS versi 22. Hasil uji linieritas menunjukkan bahwa data hasil penelitian menujukkan memiliki hubungan linier, sebagaimana disajikan dalam Tabel 6 berikut. Nilai $\alpha$ hitung (sig. $\alpha$ ) sebesar 0,063 lebih besar dari 0,05. 
Tabel 6. Uji-linieritas dengan ANOVA Table

\begin{tabular}{|c|c|c|c|c|c|c|c|}
\hline & & & $\begin{array}{l}\text { Sum of } \\
\text { Squares }\end{array}$ & df & $\begin{array}{c}\text { Mean } \\
\text { Square }\end{array}$ & $\mathrm{F}$ & Sig. \\
\hline \multirow{5}{*}{$\begin{array}{c}\text { Prestasi } \\
* \\
\text { Insoskel }\end{array}$} & \multirow{3}{*}{$\begin{array}{c}\text { Between } \\
\text { Groups }\end{array}$} & (Combined) & 287.336 & 34 & 8.451 & 11.247 & .000 \\
\hline & & Linearity & 235.561 & 1 & 235.561 & 313.485 & .000 \\
\hline & & $\begin{array}{l}\text { Deviation from } \\
\text { Linearity }\end{array}$ & 51.775 & 33 & 1.569 & 2.088 & .063 \\
\hline & \multicolumn{2}{|c|}{ Within Groups } & 70.634 & 94 & .751 & & \\
\hline & \multicolumn{2}{|c|}{ Total } & 357.971 & 128 & & & \\
\hline
\end{tabular}

Sumber: Print-out SPSS versi 22, 2016.

Analisis korelasi dan regresi

Berhubungan persyaratan uji-asumsi statistik telah terpenuhi maka analisis korelasi dan regresi dapat dilakukan untuk menguji hipotesis. Hipotesis dalam penelitian ini ialah:

1. $\mathrm{H}_{0}$ : Kualitas interaksi sosial di lingkungan keluarga berpengaruh tidak signifikan terhadap prestasi belajar siswa SMA Negeri 5 Samarinda.

2. Ha : Kualitas interaksi sosial di lingkungan keluarga berpengaruh signifikan terhadap prestasi belajar siswa SMA Negeri 5 Samarinda.

Tabel 7. ANOVA $^{\mathrm{a}}$

\begin{tabular}{|c|c|c|c|c|c|c|}
\hline & Model & Sum of Squares & Df & Mean Square & $\mathrm{F}$ & Sig. \\
\hline \multirow[t]{3}{*}{1} & Regression & 235.561 & 1 & \multirow{3}{*}{$\begin{array}{r}235.561 \\
.964\end{array}$} & \multirow[t]{3}{*}{244.395} & \multirow[t]{3}{*}{$.000^{\mathrm{b}}$} \\
\hline & Residual & 122.409 & 127 & & & \\
\hline & Total & 357.971 & 128 & & & \\
\hline
\end{tabular}

a. Dependent Variable: Prestasi (Y)

b. Predictors: (Constant), Insoskel (X)

Berdasarkan hasil perhitungan statistik pada tingkat kekeliruan $\alpha$ sebesar 0,05 maka jika $\alpha$ hitung (sig. $\alpha$ ) lebih besar dari 0,05 menolak hipotesis alternatif $\left(\mathrm{H}_{1}\right)$ dan menerima hipotesis nul $\left(\mathrm{H}_{0}\right)$. Sebaliknya jika $\alpha$ hitung (sig. $\alpha$ ) lebih kecil dari 0,05 menerima hipotesis alternatif dan menolak hipotesis nul. Hasil analisis regresi linier menyimpulkan bahwa $\alpha$ hitung (sig. $\alpha$ ) sebesar 0,000 lebih kecil dari 0,05 yang berarti kualitas interaksi sosial di lingkungan keluarga berpengaruh signifikan terhadap prestasi belajar. 
Tabel 8. Model Summary

\begin{tabular}{|c|c|r|r|r|r|r|r|r|r|}
\hline \multirow{2}{*}{ Model } & \multirow{2}{*}{$\mathrm{R}$} & \multirow{2}{*}{$\begin{array}{c}\mathrm{R} \\
\text { Square }\end{array}$} & \multirow{2}{*}{$\begin{array}{c}\text { Adjusted } \\
\mathrm{R} \text { Square }\end{array}$} & $\begin{array}{c}\text { Std. Error } \\
\text { of the } \\
\text { Estimate }\end{array}$ & $\begin{array}{c}\text { R Square } \\
\text { Change }\end{array}$ & $\begin{array}{c}\mathrm{F} \\
\text { Change }\end{array}$ & $\mathrm{df1}$ & $\mathrm{df2}$ & $\begin{array}{c}\text { Sig. F } \\
\text { Change }\end{array}$ \\
\hline 1 & $.811^{\mathrm{a}}$ & .658 & .655 & .98176 & .658 & 244.395 & 1 & 127 & .000 \\
\hline
\end{tabular}

a. Predictors: (Constant), Insoskel (X)

Selanjutnya derajat hubungan variabel kualitas interaksi sosial dengan variabel prestasi belajar siswa adalah sebesar 0,811 termasuk pada kategori hubungan sangat tinggi (Arikunto, 2009). Derajat pengaruh kualitas interaksi sosial di lingkungan keluarga terhadap prestasi belajar ialah 0,658 atau 65,8\%. Jadi prestasi belajar siswa di SMA Negeri 5 Samarinda 65,8\% ditentukan oleh faktor kualitas interaksi sosial di lingkungan keluarga, sedangkan 34,2\% ditentukan faktor lain.

Tabel 9. Coefficients ${ }^{\mathrm{a}}$

\begin{tabular}{|c|c|c|c|c|c|}
\hline \multirow[t]{2}{*}{ Model } & \multicolumn{2}{|c|}{ Unstandardized Coefficients } & $\begin{array}{c}\text { Standardized } \\
\text { Coefficients }\end{array}$ & \multirow[t]{2}{*}{$\mathrm{t}$} & \multirow[t]{2}{*}{ Sig. } \\
\hline & $\mathrm{B}$ & Std. Error & Beta & & \\
\hline $\begin{array}{cc} & \text { (Constant) } \\
& \text { Insoskel }\end{array}$ & $\begin{array}{r}40.412 \\
.162\end{array}$ & $\begin{array}{l}.360 \\
.010\end{array}$ & .811 & $\begin{array}{r}112.103 \\
15.633\end{array}$ & $\begin{array}{l}.000 \\
.000\end{array}$ \\
\hline
\end{tabular}

a. Dependent Variable: Prestasi (Y)

Tabel 9 di atas menyajikan persamaan atau formula untuk memprediksi hubungan kualitas interaksi sosial di lingkungan dengan prestasi belajar dalam bentuk matematisnya adalah $P=\beta o+\beta 1 X$. Prestasi belajar diberi simbol $\mathrm{P}$ dan koefisien beta dengan $\beta_{1}$, sedangkan $\beta$ o adalah konstanta. Dengan berpedoman pada Tabel 9 maka persamaan tersebut adalah $P=40,412+0,162 X$. Sesuai dengan bersamaan ini jika skor kualitas interaksi sosial sebesar 40 maka prestasi belajar yang diperoleh sebesar 46,892, dan jika skor kualitas interkasi sosial sebesar 50 maka prestasi belajar yang diperoleh sebesar 48,512.

\section{B. Pembahasan Penelitian}

Bertitik tolak pada data hasil penelitian ini, pada dasarnya ada dua pokok permasalahan yang perlu mendapat perhatian. Pertama adalah melihat pengaruh dan kontribusi kualitas interaksi sosial di lingkungan keluarga terhadap prestasi belajar yang diperoleh siswa. Kedua adalah melihat derajat hubungan antara interaksi sosial di lingkungan keluarga dengan prestasi belajar siswa. Selanjutnya dilakukan uji hipotesis 
terhadap parameter koefisien regresi dan korelasi. Tujuan pengujian ini untuk melihat ada tidaknya hubungan antara variabel kualitas interaksi sosial di lingkungan keluarga dengan prestasi belajar siswa. Berdasarkan hasil perhitungan perhitungan statistik analisis regresi diketahui koefisien regresi atau $\beta_{1}$ nilainya sebesar 0,162 , sedangkan konstanta atau $\beta o$ sebesar 40,412. Dengan demikian formulasi matematik dari persamaan regresi adalah $P=40,412+0,162 X$.

Jika mencermati persamaan regresi ini maka dapat diketahui bahwa koefisien regresi mempunyai nilai positif, yang berarti bahwa setiap peningkatan satu satuan kualitas interaksi sosial di lingkungan keluarga akan memberikan efek meningkatkan prestasi belajar siswa sebesar 0,162 ditambah konstantanya sebesar 40,412. Nilai konstanta menggambarkan nilai mutlak terrendah yang mungkin dicapai tanpa ada faktor kualitas interaksi sosial. Selanjutnya perhitungan terhadap derajat hubungan (korelasi) antara variabel kualitas interaksi sosial di lingkungan keluarga dengan prestasi belajar siswa diketahui koefisien korelasi $\mathrm{r}$ sebesar 0,811 dan koefisien determinasi $\mathrm{R}^{2}$ sebesar 0,658 . Hal ini berarti $65,8, \%$ hubungan kedua variabel tersebut mengikuti pola jika kualitas interaksi sosial di lingkungan keluarga meningkat, akan terjadi peningkatan pada prestasi belajar siswa.

Tinggi rendahnya prestasi belajar siswa 65,8\% ditentukan oleh variabel kualitas interaksi sosial di lingkungan keluarga, sedangkan selebihnya ditentukan oleh faktor lain sebesar $34,2 \%$. Ini memberi makna terdapat 34,2\% faktor di luar kualitas interaksi sosial di lingkungan keluarga yang menentukan tinggi-rendahnya prestasi belajar siswa. Atau dengan kata lain, kualitas interaksi sosial di lingkungan keluarga bukan satu-satunya faktor yang memberikan kontribusi terhadap keberhasilan belajar siswa di SMA Negeri 5 Samarinda.

Berangkat dari kenyataan ini perbaikan kondisi keluarga merupakan hal yang mutlak, karena hal tersebut akan memberikan dampak positif bagi peningkatan prestasi belajar di sekolah. Faktor-faktor lain yang mungkin diduga berpengaruh terhadap prestasi belajar siswa adalah pendidikan orang tua, kompetensi guru di sekolah dan daya dukung lingkungan masyarakat. Hal ini sejalan dengan pendapat Amien (1994) bahwa kondisi obyektif siswa dibagi dalam tiga macam. yaitu: (1) kondisi fisik dan mental siswa, (2) kondisi sosial-ekonomi, dan (3) kondisi lingkungan tempat hidup siswa. Dengan demikian 
lingkungan tempat hidup siswa, terutama keluarga perlu mendapat perhatian karena anak lebih lama tinggal dengan keluarga dibandingkan di sekolah. Pendapat yang sama juga dikemukakan oleh Zamroni (1992) yang menyimpulkan bahwa kesuksesan seseorang anak di masyarakat ditentukan oleh orang-tuanya. Pernyataan ini memberi makna (arti) bahwa orang-tua mempunyai peranan yang cukup besar terhadap keberhasilan anakanaknya. Hal ini mudah dipahami, karena fungsi dari orang-tua itu sendiri adalah memberikan pelayanan pendidikan kepada anak-anaknya, sehingga mencapai kedewasaannya.

\section{SIMPULAN}

Interaksi sosial di lingkunan keluarga tidak dapat dipisahkan dalam proses pendidikan anak di lembaga pendidikan sekolah. Interaksi sosial merupakan bagian integral dari keberhasilan siswa di sekolah. Dengan demikian perbaikan pola interaksi orang tua dan anak seyogyanya dibentuk sedemikian rupa sehingga anak dapat berkembang sesuai potensi. Orang tua perlu memberi fasilitas yang memungkinkan anak melakukan tindakan belajar. Secara umum kualitas interaksi sosial siswa di lingkungan pada kategori cukup. Begitu juga prestasi belajar siswa di SMA Negeri pada umumnya pada kategori cukup.

Jika kontribusi kualitas interaksi sosial di lingkungan keluarga sebesar 65,8\% terhadap prestasi belajar di SMA Negeri 5 Samarinda maka perlu membangun sinergi yang harmonis antara pihak sekolah dengan orang tua siswa. Sekolah bukan sebagai faktor penentu yang dominan terhadap keberhasilan pendidikan siswa tetapi merupakan bagian dari keberhasilan tersebut. Komunikasi orang tua dengan pihak sekolah perlu diwujudkan secara produktif untuk menghindari kesalahpaman yang berakibat buruk bagi perkembangan jiwa anak. Kedudukan orang tua dan sekolah pada dasarnya sama yaitu membantu siswa/anak menemukan dan mengembangkan potensi yang dimilikinya. Orang tua seyogyanya memahami makna sekolah bagi anaknya yang mengikuti pendidikan di sekolah. Begitu juga, sekolah sebagai orang tua kedua dapat berfungsi sebagaimana mestinya. 


\section{DAFTAR PUSTAKA}

Aditya, IG. dkk. (2013). Pengaruh Partisipasi Orang Tua Dalam Mendidik di Lingkungan Keluarga Terhadap Pretasi Belajar Siswa. Laporan Penelitian. Fakultas Ekonomi dan Bisnis Universitas Ganesha. Singaraja. Diakses dari http://ejournal.undiksha. ac.id/index.php/JJPE/article/view/1270 pada tanggal 15 Agustus 2016

Al-Muyassar. (2011). Al-Qur'an dan Terjemahannya Juz 1 s/d 30 (Transliterasi). Bandung. Sinar Baru Offset

Amien, Mohammad. (1994). Filsafat Pendidikan. Yogyakarta: PPS IKIP Yogyakarta

Arikunto, Suharsimi. (2009). Prosedur Penelitian Suatu Pendekatan Praktik (Revisi V), Jakarta: Rineka Cipta

Astuti, D.A.P. (2014). Pengaruh Motivasi Belajar dan Lingkungan Keluarga Terhadap Prestasi Belajar Kewirausahaan Pada Kelas X di SMK Muhammadyiah Kartasura Tahun Ajaran 2014/2015. Skripsi. Program Studi Pendidikan Akuntansi FKIP Universitas Muhammadiyah Surakarta. Diakses dari http://eprints.ums.ac.id/ pada tanggal 14 Agustus 2016.

Dasmo, dkk. Pengaruh Tingkat Pendidikan dan Pola Asuh Orang Tua Terhadap Prestasi Belajar IPA. Jurnal Formatif Vol. 2 No. 2: 132-139. Diakeses dari http://journal.lppmunindra.ac.id/ tanggal 21 Agustus 2016.

Dimyati dan Mudjiono. (1999). Belajar dan Pembelajaran. Jakarta: Bumi Aksara.

Fitriastuti. Febriani. (2013). Pengaruh Interaksi Sosial Dalam Keluarga dan Minat Belajar Siswa Terhadap Prestasi Belajar Siswa. Jurnal OIKONOMIA Vol. 2 No. 3: 183-188 Tahun 2013. Diakses dari http://ejournal.umpwr.ac.id/pada tanggal 19 September 2016.

Helmawati. (2014). Pendidikan Keluarga. Bandung: Remaja Rosdakarya.

Heryanto, (1996). Pengaruh Daya Dukung Sosial Ekonomi Orang Tua Terhadap Prestasi Belajar Siswa. Laporan Penelitian. Samarinda: FKIP Unmul.

Nasruddin. (2009). Kerjasama Orang Tua dan Guru Dalam Meningkatkan Prestasi Belajar Anak. Jurnal Serambi Ilmu Vol. 7 No. 1 halaman 57-66.

Slameto. (2010). Belajar dan Faktor-Faktor yang Mempengaruhinya. Jakarta: Rineka Cipta.

Sudjana. (1996). Metoda Statistika. Edisi ke 6. Bandung: Penerbit Tarsito.

Violita, F. (2013). Pengaruh Lingkungan Keluarga dan Fasilitas Belajar Terhadap Prestasi Belajar Siswa Kelas X Administrasi Perkantoran di SMK Negeri 1 Payakumbuh. Skripsi. Fakultas Ekonomi Negeri Padang. Diakses dari http://ejournal.unp.ac.id/students/index.php /pek/article/viewFile/391/218 pada tanggal 14 Agustus 2016.

Wahyudin, M.M. (2009). Pengaruh Perhatian Keluarga Terhadap Prestasi Belajar Siswa Pada Pelajaran Matematika (Studi Kasus di SMP NU Karangampel Kabupaten Indramayu). Jurnal EduMa, Vol. 1, No. 2: 165-172, Desember 2009. Diakes dari https://edumajournal.files.wordpress.com/ pada tanggal 15 Agustus 2016. 
Widana, N.N.W.S.S. (2016). Pengaruh Disipilin dan Lingkungan Terhadap Prestasi Belajar Ilmu Pengetahuan Sosial Siswa Kelas VIII SMP Negeri 3 Singaraja.Jurnal Program Studi Pendidikan Ekonomi (JPPE) Volume: 7 Nomor: 2: 1-11 Tahun: 2016. Diakses dari http://ejournal.undiksha.ac.id/index.php/JJPE/article/view/1270 pada tanggal 19 September 2016.

Widhirahmadi, Arsawan. (2015). Pengaruh Kondisi Lingkungan Keluarga dan Motivasi Belajar Terhadap Prestasi Belajar Pada Siswa Kelas VII SMP Negeri 5 Kebumen Tahun Pelajaran 2012/2013. Skripsi. Pendidikan Ekonomi FKIP Universitas Muhammadiyah. Purworejo. Diakes dari http:// ejournal.umpwr.ac.id/ pada tanggal 19 September 2016.

Wirdhana dkk., (2015). Buku Pegangan Kader Tentang Bimbingan dan Pembinaan Keluarga Remaja. Jakarta: BKKBN.

Zamroni. (1992). Pengantar Pengembangan Teori Sosial. Yogyakarta: Tiara Wacana. 